\title{
Oneyda Alvarenga escreve a Mário de Andrade
}

\author{
Marilda Ionta ${ }^{1}$
}

\section{Resumo}

As cartas de Oneyda Alvarenga endereçadas ao escritor Mário de Andrade são objetos-lembranças, objetos-relíquias, dotados da potencialidade de lembrar a relação de educação, trabalho e amizade que os uniram. Além disso, essas cartas são documentos literários marcados por uma escrita de si, no sentido apontado pelo filósofo Michel Foucault, que permitem aos indivíduos traçar retratos singulares de si mesmo. Neste texto, busco me aproximar dos rascunhos da existência que Oneyda Alvarenga construiu nas redes intersubjetivas da amizade e escrita epistolar com Mário de Andrade. Assim, leio suas cartas como documentos que guardam uma literatura de caráter autógrafo tão transgressiva quanto aquela que visa transpor os limites da linguagem, pois, no caso específico da escrita contida nas missivas de Oneyda Alvarenga, tratava-se de ultrapassar os limites de si mesma, de se (re)construir na e pela prática da escrita cotidiana.

\section{Palavras-chave}

Escrita de si, amizade, gênero, correspondência.

Recebido em 20 de agosto de 2012

Aprovado em 8 de março de 2013

IONTA, Marilda. Oneyda Alvarenga escreve a Mário de Andrade. Revista do Instituto de Estudos Brasileiros, Brasil, n.57, p. 161-180, 2013. DOI: http://dx.doi.org/10.11606/issn.2316-901X.v0i57p161-180

1 Universidade Federal de Viçosa (UFV, Viçosa, MG, Brasil). 


\title{
Oneyda Alvarenga Writes to Mário de Andrade
}

\author{
Marilda Ionta
}

\begin{abstract}
Oneyda Alvarenga's letters addressed to the writer Mário de Andrade are here considerer as memory-objects and relic-objects, endowed with the ability to revive the relationship of education, work and friendship by which they were united. Moreover, these letters are literary documents of a writing of itself, in the meaning suggested by Michel Foucault, by which individuals are able to build images of themselves. In this work, I have approached the poetic of itself formulated by Oneyda Alvarenga in the intersubjective networks of friendship and letter writing with Andrade. Their letters were read as documents, which retain a literature of themselves. This literature can be considered as transgressive as the literature that sought to overcome the limits of language. In the letter writing of Oneyda Alvarenga, this actually meant to overcome the limits of herself and to (re) build herself in and by the action of daily writing.
\end{abstract}

Keywords

Writing of itself, gender, friendship, correspondence. 


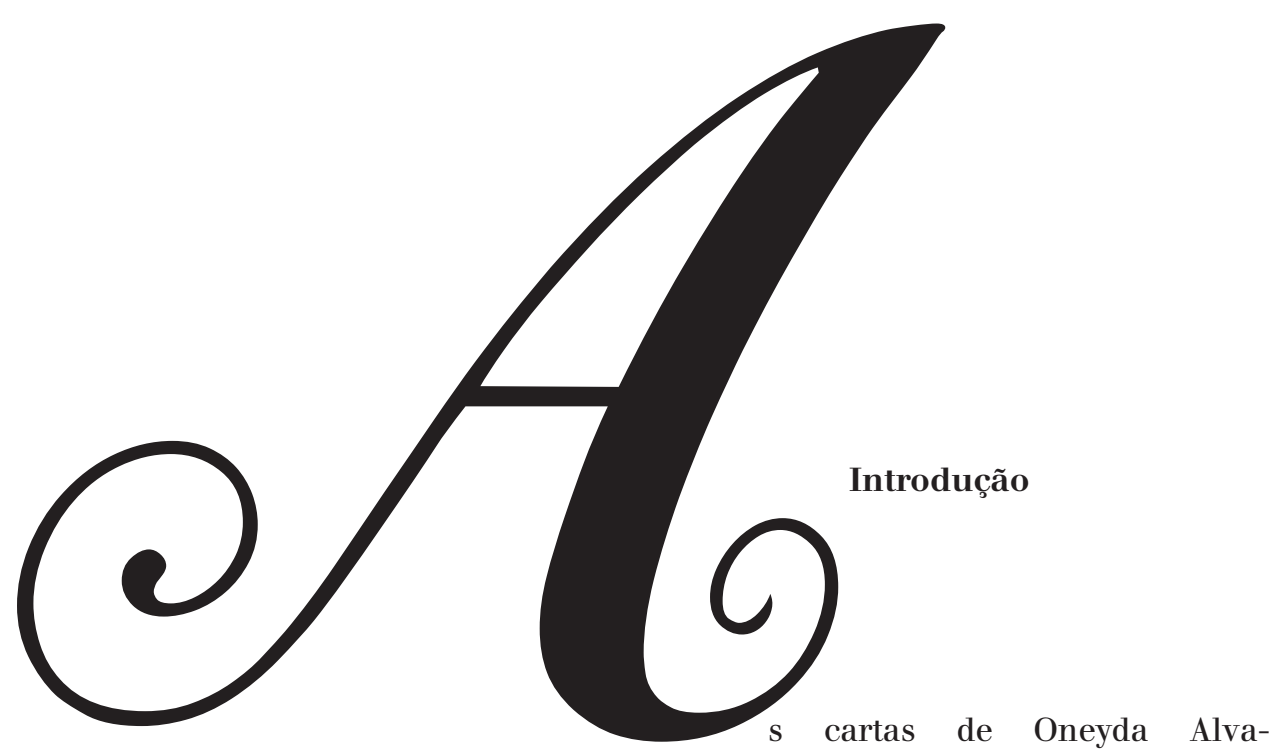

renga endereçadas ao escritor Mário de Andrade podem ser lidas como documentos/monumentos, isto é, como uma construção voluntária e/ ou involuntária da história ${ }^{2}$, e são fontes preciosas, pois essas missivas guardam o duplo aspecto de construção da memória apontado pelo historiador Jacques Le Goff.

Em 1983, Oneyda Alvarenga voluntariamente tornou pública a correspondência trocada entre ela e o escritor modernista com a publicação do livro Cartas: Mário de Andrade e Oneyda Alvarenga ${ }^{3}$. Na preparação dessa obra, ela teceu notas e comentários perpetuando uma imagem de si mesma que hoje faz parte da história da cultura no Brasil.

Assim, essas cartas podem ser percorridas como documentos de amizade entre uma jovem de 19 anos, do interior de Minas de Gerais, de formação católica e com parcos conhecimentos no campo musical, com um pensador-artista de 38 anos, já consagrado no cenário nacional. Em 1931, ocasião em que ocorreu o primeiro contato entre Oneyda Alvarenga e Mário de Andrade, o escritor já contava com uma produção artística substancial.

Nas memórias de Oneyda, o primeiro encontro foi cordial, alegre e espontâneo; ele é povoado de anjo e milagre beirando ao mítico. De acordo com suas lembranças, foi a "ajuda celestial” que a fez escolher Mário em vez de Agostino Cantu - como professor de música no Conservatório Dramático e Musical de São Paulo. As descrições míticas elaboradas em sua escritura sublinham a importância de seu encontro com o intelectual-

2 LE GOFF, Jacques. História e memória. Campinas: Ed. da Unicamp, 1996.

3 ANDRADE, Mário de; ALVAREnga, Oneyda. Cartas: Mário de Andrade e Oneyda Alvarenga. São Paulo: Duas Cidades, 1983. 
-artista, uma vez que ele é mostrado como um ponto de inflexão em sua vida, isto é, momento de mudança de rota em sua trajetória pessoal ${ }^{4}$.

O conteúdo das cartas e as formas de tratamento utilizadas pelos missivistas dão visibilidade à vida compartilhada desses amigos. Elas indicam a dinâmica da amizade, da intimidade e da proximidade construída ao longo de catorze anos de companheirismo. Podemos dizer que as correspondências trocadas entre os anos de 1932 e 1935, por ocasião das férias escolares de Oneyda do Conservatório Dramático e Musical de São Paulo, onde Mário era professor, e as intercambiadas no período de 1936 a 1940, época em que Oneyda trabalhava na Discoteca Pública Municipal de São Paulo e Mário fora afastado do Departamento de Cultura indo residir no Rio de Janeiro, documentam uma amizade com modulações próprias.

\section{A sinfonia da amizade: "Ponho sim minha mão sobre seu ombro"}

A amizade entre Mário e Oneyda nasce como uma relação de mestre-aluna e caminha para uma relação íntima entre uma jovem intelectual com um pensador-artista atormentado. Como ela conta, "durante quatorze anos houve a persistência, em nossas mãos dadas de amigos e companheiros, daquele sentido antigo em que no mesmo gesto em vez de mãos dadas ele me dera mão para que eu me guiasse" ${ }^{5}$.

Como se sabe, os elos entre Mário e Oneyda foram rompidos apenas com a morte do escritor em 1945. Dito com as palavras de Oneyda: encerrou-se quando ela chegou à Rua Lopes Chaves e encostou seu "espelhinho de bolsa, para saber se ele ainda respirava", colocando a mão na testa ainda quente de Mário, "único gesto físico de ternura” ocorrido "apenas quando findava-se uma longa convivência fraterna" e ela contava apenas com 34 anos de idade $^{6}$.

A despedida entre eles fez-se no leito de morte. Lugar simbolicamente privilegiado de transmissão de tradição, de algo que passa de geração para geração, algo que transcende a vida e a morte particulares e, simultaneamente, porta a simples existência individual, como analisa Walter Benjamin7. O lugar e momento da despedida entre Mário

4. Idem, ibidem, p. 6.

5 Alvarenga, Oneyda. Mário de Andrade um pouco. Rio de Janeiro: José Olympio/ SCET-CEC, 1974. p. 3-4.

6 Idem, ibidem, p. 24,-25.

7 BENJAMIN, Walter. O narrador. Considerações sobre a obra de Nikolai Leskov. In: . Magia e técnica, arte e política: ensaios sobre literatura e história. São Pau- 
e Oneyda, de certa forma, indicam o espírito da relação de amizade construída por eles. Oneyda foi herdeira intelectual de Mário; muito tempo depois da morte do escritor, ela se definiu como ex-aluna, mas sempre discípula. A relação de amizade entre eles é exemplar e indica que a teleia-philia, ou seja, a amizade perfeita propalada por Aristóteles, pode ser realizada, ao contrário do que ele afirmava, entre homens e mulheres e pode também ser assimétrica ${ }^{8}$.

Assim, em oposição aos tradicionais discursos filosóficos ocidentais sobre a amizade, a relação Oneyda e Mário exibe um caso lapidar de elos entre amigos na diferença, considerando a idade, o sexo/gênero e as experiências de vida. Em 1935, quando os laços entre eles se consolidam, Oneyda era uma jovem que tinha a vida pela frente. Nas palavras de Mário, ela estava no tempo em que se conquistava a felicidade; e ele, a crítica, o aplauso ou a repulsa. Essas diferenças nas histórias pessoais implicaram uma relação de amizade marcada pela assimetria. Porém, não seriam apenas as diferenças de idade, de experiências pessoais e de maturidade intelectual que deram a essa amizade uma tonalidade especial. Os interesses que os unem também distinguem esse elo amistoso de outras relações tecidas por Mário com outras missivistas ${ }^{9}$. Essa amizade adotou um franco caráter educativo, em que o amor-philia foi colocado a serviço do conhecimento. Soma-se a isso outro fator igualmente condicionante da singularidade desse vínculo amistoso: as disponibilidades subjetivas da própria Oneyda, pois ela aceitou o protetorado intelectual de Mário. Disse sim quando o escritor lhe estendeu a mão e ofereceu um ombro amigo como apoio. Em uma longa carta de 26 de maio de 1935, Mário convida Oneyda para andar pela vida juntos escrevendo:

Ponha sua mão aqui sobre o meu ombro, e vamos nos ajudando a caminhar. Até agora, como professor e aluna, qualquer ajuda,

lo: Brasiliense, 1994. p. 197-221. (Obras escolhidas 1).

8 A amizade entre homens e mulheres é vista em certas tradições filosóficas como impossíveis. Tais crenças vinculam-se à remota tradição filosófica em que, de Platão a Montaigne, de Aristóteles a Kant, postulava-se a incapacidade das mulheres de contraírem relações de amizade entre si e com o sexo oposto. Para Aristóteles (384-322 a.C.), por exemplo, as mulheres não exercem a amizade em sua plenitude, pois elas e os homens afeminados são propensos às lamentações e suas relações com o outro derivam de situações aflitivas e da tristeza. Isso faz com que elas se afastem da verdadeira amizade. ARISTÓTELES. Ética a Nicômacos. 2. ed. Trad. Mário da Gama Kury. Brasília: UnB, 1991.

9 Refiro-me, mais especificamente, às relações que Mário construiu com a artista plástica Anita Malfatti e a poetisa Henriqueta Lisboa. Veja-se IONTA, Marilda. As cores da amizade: cartas de Anita Malfatti, Oneyda Alvarenga, Henriqueta Lisboa e Mário de Andrade. São Paulo: Annablume/Fapesp, 2007. 
da minha parte era ensino ou proteção, de sua parte era gentileza e respeito. [...] Nós temos que não nos dever favores, mas chegar àquele estado magnífico de amizade em que fazer pelo outro é o mesmo que fazer por si mesmo. A gratidão é horrível, gratidão afasta. [...] Já não é mais você apenas que precisa de mim aquilo que apenas era o meu maior saber e maior experiência. [...] Desejava Oneida, intensamente que você aceitasse esta amizade que lhe peço. Deixemos o professor e a aluna pras nossas lembranças. Lembranças felizes. Agora me parece que o convívio espiritual a que chegamos exige de nós uma elevação, uma perfeição maior. ${ }^{10}$

Na resposta de Oneyda, sobressai-se a ousadia de uma jovem da década de 1930 que, contrariando as normas que regiam as relações de gênero nesse momento, escolheu, por conta própria, seu amigo fora do círculo de relações mais próximas, de vizinhança e de parentesco. Ao convite de Mário Oneyda respondeu: "Ponho sim minha mão sobre o seu ombro e lhe digo que não há alegria mais perfeita do que a de poder caminhar a seu lado"11. Essa cena epistolar inaugura uma nova etapa na relação de amizade.

Nas memórias da senhora Oneyda Alvarenga, a amizade entre eles que a correspondência documenta, encontra-se o que o Mário considerava a sua "mais legítima obra-prima: a vida de companheiro mais velho e mais experiente que ajuda e dá confiança nos outros"12. Trata-se, portanto, de um laço social que sublinha as interfaces possíveis entre amizade/educação, amizade/cuidado de si e do outro e que foi materializado nas missivas.

\section{Tramas de si na escrita epistolar}

As cartas, como documentos/monumentos, não são apenas objetos-lembranças dos elos entre amigos; são também documentos literários dotados de uma escritura peculiar. Trata-se de um gênero narrativo que guarda uma escrita de si, o sujeito e seu texto, bem como sua interação com o outro. Assim, a escrita epistolar de Oneyda Alvarenga pode ser lida no sentido apontado por Michel Foucault em seu famoso texto a "A escrita de si", ou seja, como work in progress, como uma escrita de

10 Carta a Oneyda Alvarenga, 26 de maio de 1935. In: ANDRADE; ALVARENGA, op. cit., p. 112.

11 Carta a Mário de Andrade, 31 de maio de 1935. In: ANDR ADE; ALVARENGA, op. cit., p. 114 .

12 Carta a Newton Freitas, apud ANDRADE; ALVARENGA, op. cit., p. 10. 
incompletude, como uma tentativa permanente de desprendimento de si e autorreconstrução incessante ${ }^{13}$. Como explica o filósofo, a correspondência é um texto por definição destinado ao outro que ajuda o indivíduo a aperfeiçoar-se, estimulando tanto o destinatário quanto o remetente a avaliarem cuidadosamente os fenômenos que acontecem em suas vidas cotidianas, e também auxilia na avaliação do que se passa na alma e no corpo do sujeito que escreve e daquele que lê. A fórmula é a seguinte: a escrita de si é uma ascese, um exercício com função etopoética; funciona como um operador de verdade em êthos, como uma tecnologia de si, isto é, um conjunto de técnicas que

permiten a los individuos efectuar, por cuenta propia o con la ayuda de otros, cierto número de operaciones sobre su cuerpo y su alma, pensamientos, conducta, o cualquier forma de ser, obteniendo así una transformación de si mismos con el fin de alcanzar cierto estado de felicidad, pureza, sabiduría o inmortalidad. ${ }^{14}$

A despeito das diferentes práticas e gramáticas da escrita epistolar ao longo da história, grosso modo entre antigos e modernos, a correspondência pessoal pode atuar como uma técnica de subjetivação ${ }^{15}$, como um exercício que contribui para que os indivíduos possam esculpir a si mesmos, unindo conhecimento de si e conduta ética, ou seja, logos e êthos. Nesse sentido, o gênero epistolar gera uma literatura de si que exibe simultaneamente a natureza ética e estética dessa escritura de caráter autográfico. Além disso, as correspondências guardam um caráter performático, que garante ao missivista um espaço de "autonomia individual", de aproximação e distanciamento de si e do outro. Como afirma Béatrice Didier, "la correspondance tout autant que le lieu

13 Em seus últimos cursos (1982 - 1984), Foucault problematizou as práticas de si na Antiguidade clássica, apontando com esses estudos uma nova forma de conceber o sujeito e a verdade. Nessas reflexões, destacou a importância das atividades de escrita e leitura que acompanhavam os processos de subjetivação dos gregos e romanos. Como ele demonstra, as transformações de si por si mesmo visando modos de existências estéticos que perpassam os processos de subjetivação greco-romanos acompanharam-se rapidamente de escritas - em especial, a escrita epistolar. É nesse contexto de problematizações dos processos de subjetivação que a escrita de si assume lugar importante, como prática da liberdade e como espaço de constituição da subjetividade. FOUCAULT, Michel. A escrita de si. In: . O que é um autor?. Lisboa: Vega, 1992. p. 129-160.

14. FOUCAULT, Michel apud MOREY, M. Tecnologías del yo, y otros textos afines. Barcelona: Paidos, 1990. p. 48.

15 Veja-se IONTA, Marilda. A gramática das cartas e amigos, op. cit., p. 76-85. 
d'une recherche de l'identité, est celui de l'eclatement, de la disperson de cette identite" ${ }^{16}$. Trata-se de uma escrita nômade fluida.

Assim é plausível pensar que, na tensão da escritura das cartas, Mário e Oneyda foram colorindo retratos muito singulares para si e para seu destinatário, elaborando nessa literatura privada e íntima poéticas de si mesmos. Neste texto suponho que nas redes da amizade e da escrita epistolar Oneyda produziu uma literatura tão transgressiva quanto aquela que visa transpor o limite da linguagem, tão desejada por ela e realizada brilhantemente por Mário, pois, no caso específico da literatura de si que ela produziu nas cartas, tratava-se de reinventar a si mesma na e pela prática da escrita cotidiana. E qual foi a poética de si construída por Oneyda Alvarenga quando ela escreve a Mário Andrade?

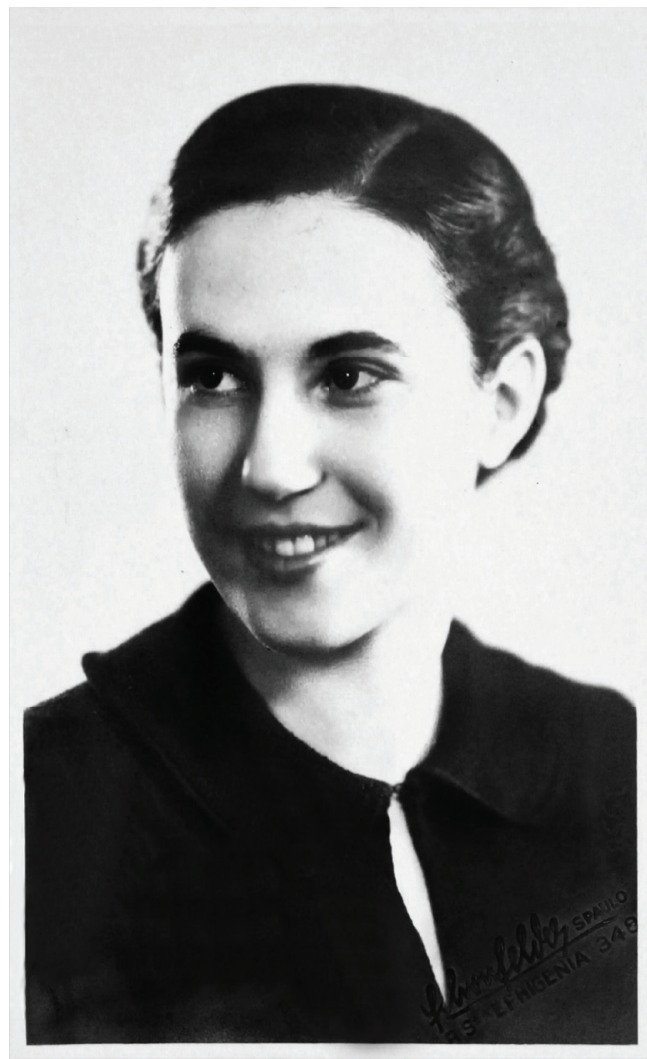

Oneyda Alvarenga, 1938. Fonte: Fundo Mário de Andrade, IEB-USP.

16 DIDIER, Beatrice. La correspondance de Flaubert et George Sand. Les amis de Georg Sand. Paris: Nouvelle série, 1989. p. 26. 
Para seguir o insólito caminho trilhado por Oneyda na reinscrição de si mesma, começo por trecho de uma de suas cartas, escrita em 2 de fevereiro de 1933, pois ela pode auxiliar na compreensão da relação que a moça nascida em Varginha estabeleceu consigo mesma e com seu destinatário amigo:

\section{Seu Mário,}

Muito obrigada pela sua carta, que me trouxe grande alegria. [...] O motivo disso não lhe é desconhecido, pois que o senhor se conhece bem: parece que sua eterna energia, a sua estabilidade, tudo o que no senhor indica uma criatura dona de si tem força comunicativa. E é por esse motivo que ainda planejo amolá-lo muito, enquanto eu tiver vida e saúde e talvez até depois de morta... Lamento que tenha arranjado uma criatura inquieta, ou melhor, desorientada e desequilibrada que o acha com cara de lhe servir de esteio, sem ter dado ao trabalho de lhe perguntar se se acha ou não com vocação de consolador dos aflitos. Entretanto, acredito que não lhe falta mesmo essa vocação, desde que o senhor vem me aturando com tão boa vontade há quase dois anos.

Nem por brincadeira posso discordar do que me diz a meu respeito. É a verdade. E, sendo assim, não pode duvidar da imensa utilidade de suas palavras. Vou seguir seus conselhos e hei de me transformar. Creio firmemente que posso conseguir, seguindo-os, a estabilidade, a segurança que invejo no senhor. Mas não acredito que a cura seja rápida nem muito fácil. O mal é velho e as velhas doenças um caso sério. [...] Sempre gostei de vida sossegada, de morar num canto, isolada e desconhecida. Talvez seja por pressentir isso que Climène [outra aluna de Mário] me falou um dia, como lhe contei, que nasci para criar galinhas. Acho que está aí um destino que me convinha, fora de brincadeira. Morar quieta num sítio, onde pudesse ler, escrever, trabalhar em paz e à vontade, sempre foi meu ideal. [...] Gosto da vida das cidades grandes pela independência que se tem, porque se pode procurar um ambiente mais largo pra viver, evitando morrer com o espírito sufocado. Mas, quanto ao resto, sou tal e qual um tio meu: não nasci pra respirar gasolina e pó de asfalto. [...]

Desejo que o senhor se divirta muito agora em fevereiro ${ }^{17}$ como planeja.

17 Os votos de Oneyda estão atrelados à afirmação contida na carta de Mário de que ele estava precisando de "muito riso e pouco siso" para ver se esquecia da morte na alma 
Lamentavelmente, não posso também perder o siso por uns dias: detesto carnaval. E não seria na minha terra que iria perder o juízo... Uma moça distinta, sensata, recatada etc..., e além do mais filha do seu Orpheu, está proibida de se divertir à vontade. [...] Perdoe a amolação $[\ldots]^{18}$.

Nessa carta, Oneyda cria um autorretrato cujos contornos traçam a imagem de uma menina tímida, medrosa, recatada, uma moça distinta e sensata; é a "filha do seu Orpheu" que é materializada discursivamente e a quem estava interditado o prazer e a diversão. Mais do que isso, "criar galinhas" e morar no interior livre de "pó de asfalto" e cheiro de gasolina é visto como um destino que lhe convinha.

Mas a imagem da moça bem-comportada que ela envia a seu destinatário também é uma criatura inquieta e desorientada que, se não tivesse encontrado Mário, teria se perdido no vazio e na inutilidade. Nesse sentido, a sedução pela forma de vida simples do interior mistura-se, nas cartas de 1932 a 1935, com o desejo de independência e com a vontade de usufruir as oportunidades que a cidade grande poderia lhe oferecer e, especialmente, seu professor.

Como ela revela, seu interesse na relação é conquistar a segurança, a sabedoria e a arte de pertencer a si mesma como seu mestre possuía. Assim, nas cartas de Oneyda, sua timidez opõe-se à desenvoltura do mestre; seu medo, à coragem e fortaleza de seu preceptor, uma vez que tudo em Mário lhe indica "uma criatura dona de si"19.

Por sua vez, ela olha para si mesma como uma mulher perturbada, desequilibrada, doente, mas acredita em sua cura. O que Oneyda apresenta como sendo suas patologias? Entre outras coisas, seu páthos ${ }^{20}$ reside em sua ignorância acadêmica, em seu medo e insegurança sobre

que a guerra civil paulista lhe causou; Mário se refere à Revolução Constitucionalista de $193^{2}$.

18 Carta a Mário de Andrade, 2 de fevereiro de 1933. In: ANDRADE; ALVARENGA, op. cit., p. 47-49.

19 Em notas de seu livro Cartas: Mário de Andrade e Oneyda Alvarenga, de 1983, ela narra que a "estabilidade não era tanta assim, apenas assim aparecia aos alunos e aos simples conhecidos. Nem era possível num artista, [...] aquilo que eu imaginava um equilíbrio emocional absoluto, tanto ele me falava em como sabia superar tristezas, decepções, injustiças, e tocar o barco pra frente. Bem, acho que estou fazendo confusão: dominar-se não significa falta de sofrimento, nem é isso que quer dizer". ANDRADE; ALVARENGA, op. cit., p. 49.

20 Para os gregos, o conceito de páthos aplicava-se tanto à paixão da alma quanto à doença física. Na Paideia grega, formar-se e cuidar-se eram atividades correlatas. Veja-se FOUCAULT, Michel. História da sexualidade III: o cuidado de si. Rio de Janeiro: Graal, 1985 . 
seus valores pessoais. Esses males, na opinião da moça, são velhos, e sua cura, demorada: "não acredito que a cura seja rápida nem muito fácil. O mal é velho e as velhas doenças são um caso sério" ${ }^{21}$. Ela utiliza uma linguagem médica para se diagnosticar. Apresenta-se como doente e solicita cuidados de seu professor, aquele que supostamente detém os remédios para a cura de seu mal.

Nessa direção, Oneyda reconhece a autoridade de Mário e, visando sua purificação, resolve segui-lo, acompanhá-lo, obedecer-lhe. Ela, por exemplo, não evita mostrar sua direção intelectual com o intuito de "curar-se", de livrar-se do espírito "iluminado à lamparina"22. Aceita a obrigação de dizer o que se passa em seu corpo e sua alma; de contar o que está fazendo, até mesmo no período de suas férias escolares; concordara em escrever semanalmente cartas/relatórios sobre suas atividades. Talvez, essa prática epistolar tenha contribuído para Oneyda afirmar que as cartas para ela sempre foram uma forma de trabalho.

Cabe lembrar que tanto nas cartas escritas na fase de 1932 a 1935, isto é, no período em que ainda era aluna de Mário, quanto nas redigidas no intervalo de 1935 a 1940, quando era diretora da Discoteca Pública Municipal de São Paulo, Oneyda adota uma postura narrativa marcada pela humildade e pela submissão. Na segunda fase da troca epistolar, a moça tímida cede lugar à mulher insegura sobre suas capacidades intelectuais e profissionais. Sente-se com uma eterna falta de conhecimentos e, por isso, incapaz de caminhar sozinha, de onde deriva a necessidade não mais do professor, mas do "amigo-pai" 23 .

Dessa forma, nas cartas tanto da jovem aluna quanto da mulher adulta, Oneyda adota uma postura narrativa humilde e temperada com fortes doses de desvalorização de si. Em suas missivas, ela reativa a imagem da mulher humilde, boa, suavemente submissa, em outras palavras, brotam de sua escrita imagens femininas que reativam os contornos da "fada do lar" para usar uma expressão consagrada por Virgínia Woolf ${ }^{24}$. Oriundas das relações de gênero predominantes nas sociedades patriarcais que preservam as hierarquias de gêneros e reservam o espaço privado, o lar, às mulheres e o espaço público, aos

21 Carta a Mário de Andrade, 2 de fevereiro de 1933. In: ANDRADE; ALVARENGA, op. cit., p. 47-49.

22 Carta a Mário de Andrade, 19 de junho de 1932. Idem, ibidem, p. 21.

23 Diz Oneyda em suas memórias que, por volta dos anos 1950, chegou a entender seu amigo-pai mais profundamente e a encontrá-lo em sua realidade. Idem, ibidem, p. 99 .

24. WOOLF, Virgínia. Profissão para mulheres e outros artigosfeministas. Porto Alegre: L\&PM, 2012 (Coleção L\&PM Pocket). 
homens. Nessa direção, ela parece medir sua alma com os parâmetros da ideologia da domesticidade feminina, na qual a mulher é observada com desprezo e pena. Esse imaginário socialmente misógino acabou comprometendo a opinião que as próprias mulheres desenvolveram e desenvolvem a respeito de si mesmas.

Certamente por isso, todas as vezes que lemos as cartas de Oneyda Alvarenga enviadas a Mário temos sempre a impressão de uma mulher disciplinada, trabalhadora, bem-vestida, comportada e obediente. Enfim, de uma moça bela e fiel que desejava ser conduzida pelo escritor. Entretanto, das cesuras, rachaduras da escrita epistolar de Oneyda brotam outras forças e questões que borram a imagem da mulher frágil e insegura, isto é, quebram o feitiço de suas cartas.

Uma escrita sorrateira que não está dita em palavras, que não tem o poder de totalização, de fixar linhas identitárias, se faz presente em lances e golpes e se desenvolve no interior da ordem discursiva de sua escritura. Essa escrita silenciosa subverte a imagem idealizada de mulher, ou melhor, estilhaça a imagem da bela fiel elaborada por ela em suas missivas.

Nessa linha de raciocínio, julgo problemático aceitar em princípio, sem mediações, a imagem estruturada da bela fiel oferecida por Oneyda ao leitor em suas cartas. Pois é difícil imaginar que uma moça de dezenove anos - que decide sair de sua terra natal para profissionalizar-se em música em São Paulo - seja tão submissa e dócil, como a Oneyda que ela nos dá a ler nas cartas. Sua conduta não parece comum às moças de sua idade, de sua classe social e de seu tempo, marcado por uma intensa ideologia da domesticidade feminina.

Se a Oneyda enviada por ela a Mário vai sempre bem-vestida e comportada, não se pode dizer a mesma coisa sobre o sujeito da enunciação, isto é, aquele que escreve. Como reconhece Gilles Deleuze, as cartas, em virtude de seu gênero, conservam a dualidade de dois sujeitos: um sujeito de enunciação como forma de expressão que escreve a carta; e um sujeito de enunciado como forma de conteúdo do qual a carta fala ${ }^{25}$. Essa duplicidade de sujeitos evocados pelo autor é bastante sugestiva para pensar a correspondência de Oneyda Alvarenga.

Nas cartas/relatórios enviadas a Mário, narra minuciosamente suas tarefas cotidianas. Nelas, é visível a aplicação que ela faz sobre seu corpo e sua alma de uma série de exercícios, visando sua transformação. Ler, escrever, estudar, fazer exercícios poéticos e musicais e pesquisar música popular são atividades que preenchem as linhas de suas missivas. Tais exercícios narrados nas cartas, ao lado do refrão do desânimo e

25 DELEUZE, Gilles. Kafka: por uma literatura menor. Rio de Janeiro: Imago, 1977. 
dos choramingos de aluna, revelam, ao mesmo tempo, a existência de uma moça dotada de determinação, coragem e vontade de transgredir o mundo para o qual havia sido destinada. Enfim, emerge uma jovem rebelde convicta de sair do lugar onde estava fixada, de não se encalhar na identidade da "filha do seu Orpheu", a quem - por ser jovem e mulher - estava interditado, entre outras coisas, o mundo do conhecimento e a opção do campo artístico como profissão na esfera pública.

Nas cesuras de sua escrita brotam o desejo transgressor para uma mocinha do interior de Minas Gerais, de sair do espaço de privação e invadir o mundo público. Em carta de abril de 1935, Oneyda expõe a Mário sua insatisfação com a vida interiorana e com seu trabalho de professora na Escola Normal dos Santos Anjos, dizendo: "Como se pode viver no interior de atividades artísticas? E que outra saída Varginha me oferece, senão de me meter numa classe de alunas da minha idade e ignorantes como uma porta? Também sonho com Belo Horizonte e mamãe sonha comigo"26.

Como indica essa missiva, a moça tímida sonha com outra vida, ela quer viver em um centro urbano onde pudesse ter um ganha-pão que garantisse sua independência econômica e lhe oferecesse liberdade para realizar uma vida de artista. Esse projeto pessoal é refletido com seu interlocutor especialmente nas cartas do primeiro semestre do ano de $1935^{27}$. Nessas cartas, o "destino de criar galinhas" parece ter ficado para trás, o que é compreensível, pois, no decorrer da relação com Mário, ela havia adquirido uma nova compreensão de si e do mundo.

Como registra a correspondência de Oneyda, as leituras realizadas por ela diferenciaram-se muito do estilo literário consumido por uma parcela considerável de mulheres da classe média brasileira na década de 1930. Suas leituras distanciavam-se dos romances românticos destinados às moças, que, em sua grande maioria, veiculavam uma educação moral, doméstica e matrimonial ${ }^{28}$.

26 Carta a Mário de Andrade, 10 de abril de 1935. In: ANDRADE; ALVARENGA, op. cit., p. 101. Em sua carta anterior, de 25 de março de 1935, ela explicara a Mário que havia aceitado o emprego como professora na escola porque não gostava de depender economicamente de ninguém. Somava-se a esse fato a frágil situação financeira da família.

27 No primeiro semestre de 1935, após a conclusão do curso no Conservatório Dramático e Musical de São Paulo, Oneyda foi residir em Varginha com sua família. Nesse momento, sua correspondência adota a retórica do choramingo. Vale dizer que essa estratégia narrativa, sem dúvida, produz sentimentos em seu destinatário, que imediatamente manifesta também sua vontade de vê-la em uma cidade grande, como São Paulo ou Belo Horizonte. Ver as cartas de Mário de 6 de julho de 1935; 30 de abril de 1935; 10 de março 1935. In: ANDRADE; ALVARENGA, op. cit.

28 Segundo Susan Besse, em 1927, uma pesquisa sobre os hábitos de leitura entre as alunas do último ano da Escola Normal de São Paulo mostrou que as jovens pouco mais liam do que romances românticos. Além disso, ela aponta que durante os anos 
A correspondência de Oneyda deixa vestígios de outro aprendizado feminino. Os títulos dos livros lidos, a forma de leitura e as dúvidas relatadas em suas cartas sugerem a construção de uma sólida formação intelectual. Para isso, Oneyda aceitou as recomendações de leituras dadas por Mário. Sobre a orientação bibliográfica dada pelo mestre - que incluía psicanálise, história, filosofia e literatura -, ela recorda em 1983, em nota memorialística, que, por conta própria, já havia descoberto e lido várias histórias da filosofia. Por isso, quando Mário lhe sugeriu as leituras nesse campo de conhecimento, diz Oneyda que "Caiu a sopa no mel”, pois, desde os tempos varginhenses, ela já havia se enamorado por um campo vizinho, o da história das religiões ${ }^{29}$.

A expressão “caiu a sopa no mel” é uma forma simples, popular e metafórica de sublinhar a produtividade do poder. Como reconhece Judith Butler, na esteira do pensamento foucaultiano, "Sujeción significa el proceso de convertirse en sobordinado/a al poder y también o proceso de convertirse en sujeto" ${ }^{30}$. A frase de Oneyda enuncia não apenas que a menina estava sujeita à ação do professor, de seguir suas recomendações, mas ela se apresenta também como sujeito da ação, ou, pelo menos, como disponível à “ação", expondo com isso as ambiguidades da palavra "sujeito" e dos processos de sujeição. Isso nos leva a problematizar a relação mestre e discípula de forma mais complexa. Nessa linha de reflexão, pode-se dizer que Oneyda se apresenta também como alguém que age para se despedir do espírito "iluminado à lamparina"; é um indivíduo que se sujeita "a" para converter-se "em".

Assim, o diálogo epistolar mantido com Mário registrou, entre outras coisas, o processo de conversão de Oneyda, em especial, o momento em que ela oscilava entre uma identidade a ser recusada - a da "menina boba"31 - e outra a ser conquistada - a da mulher intelectual competente. Portanto, suas cartas descortinam um modo de vida, gestos e

1930, os efeitos potencialmente transformadores da expansão da educação formal para as mulheres foram atenuados pelos conteúdos ministrados às moças, pois os currículos destinados às jovens privilegiavam as habilidades manuais e a educação doméstica, em detrimento da formação intelectual. Sua tese é que, apesar da expansão da educação destinada às mulheres, não houve emancipação feminina e preservou-se a hierarquia de gênero. BESSE, Susan. Modernizando a desigualdade: reestruturação da ideologia de gênero no Brasil, 1914-1940. São Paulo: Edusp, 1999.

29 Carta a Mário de Andrade, 19 de junho de 1932. In: ANDRADE; ALVARENGA, op. cit., p. 22. Nas notas dessa carta, Oneyda avalia positivamente as orientações de leituras dadas por Mário.

zo BUTLER, Judith. La vida psíquica del poder. Teorías de la sujeción. Feminaria, v. 12, (22/23), p. 1, 1999.

31 Nome dado por Mário ao primeiro livro de poesia de Oneyda Alvarenga. 
atitudes que não podem ser generalizados para as moças de sua época e, principalmente, não coadunam com a figura de mulher idealizada que ela oferece a seus leitores. Imagem certamente contaminada pelo imaginário patriarcal predominante na sociedade brasileira nas primeiras décadas do século $\mathrm{XX}$, quando as mulheres eram alvos privilegiados dos discursos moralistas, médicos e das elites políticas higienistas que visavam a "utopia da cidade disciplinar", cujo ideal residia na implementação do modelo burguês de família, da ordem, do progresso, da modernidade, da civilização e na manutenção das hierarquias de gênero ${ }^{32}$.

Entre o refrão do desânimo, suas missivas guardam os convites para concertos, solicitações de colaboração para jornais com artigos sobre música e também com poesias; as dificuldades de elaboração de seu trabalho sobre linguagem musical, suas pesquisas folclóricas ${ }^{33}$. Descortina-se a face exploradora da pesquisadora de música e de tradições musicais populares, o que, aliás, era de extremo interesse para Mário. Embora seu espaço profissional - a música - possa ser associado a um campo tradicionalmente feminino, a maneira como ela se relacionara com ele difere-se da formação destinada às mulheres nessa área, pois a música não era um ornamento em sua vida. Ao longo do tempo, ela se tornou uma musicóloga, e suas pesquisas e cartas exibem a gestação de uma antropóloga. Seu trabalho Cateretês do Sul de Minas de Gerais recebeu o prêmio consagrado aos primeiros colocados no curso ministrado, no Brasil, pela francesa Diná Lévi-Strauss.

Como se pode observar, a mulher inteligente/intelectual nasceu sob o signo da música e do folclore. Aliás, uma combinação bem característica da maneira como Mário pensava a música popular brasileira, pois, para ele, o elo música-folclore era a chave para a construção de um discurso nacional sobre a música.

Nessa empreitada de Mário, Oneyda tornou-se uma companheira ideal, não para acompanhá-lo pelos salões, mas para trabalhar com ele nos espaços públicos institucionais que estavam se ampliando com a instauração do Estado Getulista. A amizade entre Mário e Oneyda é instigante para se observar o deslocamento dos espaços de poder, onde se decidiam os rumos culturais de São Paulo, ou seja, da sociabilidade dos salões privados das granes famílias para os lugares institucionalizados do Estado ${ }^{34}$.

32 RAGO, Margareth. Do cabaré ao lar: a utopia da cidade disciplinar. Rio de Janeiro: Paz e Terra, 1997.

33 Carta a Mário de Andrade, 19 de dezembro de 1934. In: ANDRADE; ALVARENGA, op. cit., p. 66-67.

34. CAMArgos, Marcia. Villa Kyrial: crônica da Belle Époque paulistana. São Paulo: Senac, 2001. 
Aos 23 anos de idade, a convite do escritor, Oneyda Alvarenga foi a São Paulo para trabalhar como escriturária na Discoteca Pública Municipal, mas não assumiu essa a função; sua tarefa era dirigir a instituição desde sua fundação. Mesmo depois do afastamento de Mário do Departamento de Cultura, em 1938, ela continuou na direção da Discoteca, deixando o posto apenas por ocasião de sua aposentadoria em 1964. Como funcionária do Estado, continuou suas pesquisas etnográficas e desenvolveu todo um trabalho de divulgação cultural da música ${ }^{35}$.

Sob sua direção, a Discoteca havia se tornado um modelo de instituição, tanto que a Sociedade de Educação Musical de Praga recorreu à Discoteca Pública Municipal de São Paulo para elaborar a organização de seus acervos ${ }^{36}$. Em 18 de agosto de 1938, com aproximadamente 26 anos, Oneyda concedeu uma entrevista ao jornal Diário da Noite, esclarecendo a organização, a função e os serviços prestados pela Discoteca. Diz ela aos jornalistas:

Porque é preciso que se lembre, e precisamente agora que vamos falar do nosso serviço de consultas de discos, que a finalidade da discoteca não é divertir, não é facultar meio de matar o tempo a duas dúzias de desocupados, nem de deleitar os ouvidos de meia dúzia de amadores esclarecidos. Conhecido como deve ser de todos o papel das Artes na cultura de um povo, seu fim é colaborar para o desenvolvimento delas, fornecendo dentro da sua esfera de ação, meios de se formarem elites artísticas capazes de illustrar a nossa vida intelectual. Dado o imenso poder socializante da música [...]. ${ }^{37}$

Nesse depoimento, não há medo nem insegurança; ao contrário, é marcado por uma linguagem estruturada e dotado de uma postura narrativa firme e racional. Além disso, deixa explícita publicamente sua concepção de política cultural. Em 1938, ela começou a promover

35 Em carta de 27 de fevereiro de 1940, ela conta a Mário o trabalho que vinha realizando na discoteca com as escolas. Diz ela, no final dessa carta, "que o estado cuide de substituir os seus horrendos programas em que se manda ensinar o que é uma semibreve, por programas de apreciação musical. E nós que fiquemos em paz, já que não temos meio nem pessoal suficiente para assumir a responsabilidade que cabe a ele". In: ANDRADE; ALVARENGA, op. cit., p. 211.

$3^{6}$ Em 28 de outubro de 1938, Sérgio Milliet escreve no jornal O Estado de São Paulo, um artigo intitulado "Discotheca Municipal", mostrando que Mário, mentor intelectual dessa instituição, já falava naquela ocasião da importância de se criarem arquivos: de palavra, de música, de práticas de danças. Oneyda foi companheira de Mário nesse tipo de trabalho. Arquivo da Discoteca Pública Municipal de São Paulo.

37 ALVARENGA, Oneyda. No mundo dos discos. Diário da Noite, 18 ago. 1938. Arquivo da Discoteca Pública Municipal de São Paulo, pasta 15. 
concertos com os discos do acervo que eram acompanhados de comentários críticos, cursos de divulgação de história da música e conferências escritas.

Nessa época, do lado Oneyda surge uma série de cartas e pedidos a Mário, buscando auxílio na condução dos trabalhos desenvolvidos na Discoteca Pública Municipal de São Paulo. Nessas missivas, Oneyda revela a relação intelectual "umbilical" construída entre eles, mas, além disso, as cartas desse período deixam também ao leitor a possibilidade de ver a erudição que ela havia adquirido no campo musical. "Por dever de ofício", escreve Oneyda, “em fins dos anos 1930 eu estava mais atualizada que ele [Mário]" em matéria de música ${ }^{38}$. Tanto que, em carta de 9 de fevereiro de 1939, o escritor avaliou a palestra da discípula, intitulada "Música instrumental no século XVIII", e concluiu que os comentários estético-sociais estavam excelentes.

A conferência estava tão boa que Mário teve dúvidas sobre até que ponto as ideias apresentadas eram mesmo de Oneyda, ou melhor, estavam expostas com palavras exclusivamente dela. Dito em outra forma, ele levanta a suspeita de plágio. Para explicar sua desconfiança, o escritor apresenta a seguinte justificativa:

[...] ela tem sua razão de ser, naquele fato, já comentado entre nós, de às vezes você expor em trabalho seu ideias minhas, ou maneiras minhas de pensar uma ideia já generalizada, que às vezes chega a servir das próprias palavras, quase do próprio texto meu. Tenho, portanto direito de imaginar você faça o mesmo com outros maiores também.

E agora vem o mais importante e perigoso desta carta. Não sou de forma alguma contra o plágio em trabalhos de qualquer natureza, e muito tenho plagiado. Já roubei ideias artísticas, processos literários e pensamentos críticos. [...] O plágio tem qualidades ótimas: enriquece a gente, desentorpese uma exposição intelectual do excesso de citações, permite [...] melhorar ideias alheias boas. Porém o plágio tem de ser consciente... Ora, justamente o que me parece é que, se houve plágio, este porventura não terá sido bem consciente, bem hábil, bem... honesto.

E si não houve, então meus parabenzíssimos, que a coisa está ótima. $[\ldots]^{39}$

38 ANDRADE; ALVARENGA, op. cit., p. 17.

39 Carta a Oneyda Alvarenga, de 9 de fevereiro de 1939. In: ANDRADE; ALVARENGA, op. cit., p. 170-171. 
A despeito da mensagem enviada por essa missiva, ou seja, a dúvida sobre a competência da jovem intelectual de realizar um trabalho excelente, a problematização central dessa carta incide sobre a fidelidade de Oneyda em relação às suas fontes de pesquisa e, especialmente, a ele, Mário, seu preceptor.

Essa carta instaura uma querela na relação deles, que lembra o adágio das "belas infiéis", apresentado pelo retórico francês Ménage, no século XVII. Sutilmente, Ménage sugere que "uma mulher - ou tradução 'fiel' só pode ser feia, e, portanto, seu contraponto afirma que toda mulher

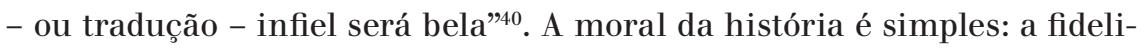
dade do tradutor ao texto original o aprisiona, não permite que ele se torne um novo criador; em contrapartida, a infidelidade o liberta, pois as traduções infiéis adquirem singularidade, beleza, originalidade e historicidade.

Ao que parece, Oneyda, como tradutora de suas fontes das quais Mário era uma peça-chave, tornou-se infiel e, portanto, bela. Tão bela que ele foi incapaz de reconhecê-la nos comentários estético-sociais das últimas páginas de sua conferência, pois ela se tornou uma criadora, levando-o à hipótese de plágio inconsciente.

Comentando esse episódio em notas contidas na obra Cartas: Mário de Andrade e Oneyda Alvarenga, ela conta-nos que bebia em muitas fontes, não apenas naquelas que ele supunha ser somente dele; e mais, relata que "naquela altura, eu tanto estudara que estava mais sabida que ele em história da música" ${ }^{41}$.

Não é preciso dizer o quanto esse acontecimento machucou a discípula, e, seguindo sua memória, foi a profunda amizade que a impediu de romper os laços criados com Mário. Diz Oneyda, "Fiquei ofendidíssima, maltratei-o sem dó" ${ }^{42}$. Passado o momento inicial da dor, ela reconsiderou as ofensas enviadas a Mário, mas mesmo assim encaminhou uma carta cujo teor era todo um trabalho de cotejamento das fontes para mostrar a ele que o trabalho era dela e que sua suposição foi extremamente infeliz.

Em 1983, quando Oneyda publica a correspondência trocada entre eles, sob a justificativa de evitar mal-entendidos, ela toma definitivamente para si a tarefa de dar ao grande público sua vida e sua obra. Com essa atitude, Oneyda Alvarenga traça os contornos da menina sabida, da

40 DÉPECHE, Marie France. A tradução feminista. Teorias e práticas subversivas. Feminismos: teorias e perspectiva. Revista de Pós-Graduação em História da UnB, v. 8, n. 1-2, p. 165, 2000.

4.1 Nota 2 de Oneyda Alvarenga à carta de 9 de fevereiro de 1939. In: ANDRADE; ALVARENGA, op. cit., p. 171.

42 ANDRADE; ALVARENGA, op. cit., p. 17. 
mulher intelectual e da poetisa gorada. Portanto, é ela quem constrói e perpetua os retratos de si e de sua amizade com Mário de Andrade.

\section{Considerações finais}

Oneyda Alvarenga, ao tornar pública sua correspondência e sua relação com o escritor, dá visibilidade ao esforço herculano de uma mulher que na década de 1930 buscou se despedir do lugar onde estava confinada, que gritou para sair do encarceramento identitário, isto é, libertar-se de sua tripla opressão: de jovem, mulher e aluna. Sua relação de amizade com Mário pode ser vista como uma prática de liberdade - exercida em um espaço intersticial às instituições como a família, a escola e o Estado - que permitiu a Oneyda constituir-se como dona de si e invadir o espaço público, ganhar os palcos nacionais, reconhecimentos internacionais e conquistar um mundo para o qual, a princípio, não havia sido destinada.

Ao revelar sua história pessoal, ela rompe o silêncio, aponta os obstáculos e mostra como encontrou, transversalmente, uma maneira própria de conduzir-se no mundo. Os fragmentos de sua existência aqui tratados são rastros do modo como ela pôde escrever a poética da sua própria vida. Uma poética de luta e trabalho incessante em projetos artísticos e culturais. Suas cartas e sua história de vida reativa experiências femininas de resistências, leva-nos a pensar em nossa atualidade e nas lutas empreendidas pelas mulheres, bem como sobre os caminhos de todas aquelas que ousaram desafiar, mesmo de maneira leve os poderes impostos social e politicamente. Para concluir, vale dizer que nas redes da amizade e da narrativa epistolar Oneyda Alvarenga escreveu nas linhas tortas da vida um belo poema, que lhe garante hoje um lugar legitimado na ordem pública e na história da cultura no Brasil.

\section{Sobre a autora}

\section{Marilda Ionta}

Professora do Departamento de História da Universidade Federal de Viçosa (UFV, Viçosa, MG, Brasil). Pós-Doutorado pela Universidade de Coimbra - Portugal .

E-mail:marilda@ufv.br 
